\title{
A talajok sav-bázis pufferkapacitásának értékelésére alkalmas módszer vizsgálata
}

\author{
RÉKÁSI MÁRK és FILEP TIBOR
}

MTA Talajtani és Agrokémiai Kutatóintézet, Budapest

A savanyú talajok javítása elvi hátterének fontos része a talajok sav-bázis pufferképességének jobb megismerése, megértése. A talajok pufferképessége ismeretének mindkét - savas és lúgos - pH-tartományban jelentősége van. A savakkal szembeni ellenálló-képesség a légköri savas ülepedés, a savanyító mütrágyák szempontjából meghatározó. A pH-t növelő hatásokkal szembeni tompítóképesség meghatározása viszont a talajjavító meszezés pontos kivitelezése, a talajjavító anyag szükséglet precíz meghatározása szempontjából nélkülözhetetlen.

A pufferképesség meghatározására sokféle módszer létezik (VAN SLYKE, 1922; FEDERER \& HORNBECK, 1985; MURÁNYI, 1987; YUAN \& LAVKULICH, 1995). Az eljárások többsége talajszuszpenziók potenciometrikus titrálásával nyert görbék értékelésével határozza meg a talaj pufferoló képességét, azonban ezek - FILEP (1991) szerint - csak a pufferhatás kvalitatív elemzésére alkalmasak. Éppen ezért FILEP (1991) egy olyan értékelési módot javasol, amellyel a pufferképesség kvantitatívan kifejezhető és a pufferképesség változási tendenciája is bemutatható. Az általa javasolt módszer hatványfüggvények titrálási görbére illesztésén alapszik. Az egyenletek a következők:

$$
p H_{x}=p H_{0}+k\left(m_{b}\right)^{q} \quad \text { és } \quad p H_{x}=p H_{0}-k\left(m_{s}\right)^{q}
$$

ahol: $p H_{x}$ a talajszuszpenzió egyensúlyi pH-ja meghatározott mennyiségủ lúg $\left(\mathrm{m}_{\mathrm{b}}\right)$, vagy sav $\left(\mathrm{m}_{\mathrm{s}}\right)$ hozzáadása után, $p H_{0}$ a szuszpenzió kezdeti $\mathrm{pH}$-ja (a titrálás zéruspontja), $k$ az egységnyi tömegủ bázis, vagy sav által előidézett kezdeti $\mathrm{pH}$-változást mutatja, $q$ pedig a $\mathrm{pH}$ változás sebességét jellemző konstans.

A FILEP (1991) által javasolt függvény a teljes görbét csak nagy hibával írja le. Ezért a görbék ellaposodó, nagyobb sav- és lúgterhelésnél bekövetkezö, nagy pufferképességet mutató - de gyakorlatilag a talaj pufferképességének kimerülését jelentő - szakaszát a kezdeti meredek szakasztól elválasztotta és a két szakaszra külön-külön határozta meg a pufferképességet jellemző függvényparamétereket.

Jelen közleményünkben további értelmezést kívánunk adni a $k$ és a $q$ paramétereknek, valamint megvizsgáljuk, hogy a $k$ és $q$ egymástól és a talaj tulajdonságaitól hogyan függenek.

Postai cím: RÉKÁSI MÁRK, MTA Talajtani és Agrokémiai Kutatóintézet, 1022 Budapest, Herman Ottó út 15.E-mail: rekasi@rissac.hu 


\section{Anyag és módszer}

A vizsgálatokhoz Magyarország területéről származó különböző fizikai és kémiai paraméterekkel rendelkező $17 \mathrm{db}$ talajmintát használtunk fel.

A pH-értékeket 1:2,5 arányú talaj: $1 \mathrm{~mol} / \mathrm{dm}^{3} \mathrm{KCl}$-oldatból készített szuszpenzióban határoztuk meg. A humusztartalmat $(\mathrm{Hu} \%)$ Tyurin módszerével mértük (HARGITAI, 1988). A fizikai tulajdonságok közül a leiszapolható részt határoztuk meg (Li\%) VÁRALLYAY (1993) szerint. A T-értéket és a kicserélhető bázisok menynyiségét (S-érték) GILLMANN (1979) szerint határoztuk meg. Az alapvizsgálatok eredményeit az 1. táblázat tartalmazza.

A sav-bázis titrálásokat 1:20 talaj:1 $\mathrm{mol} / \mathrm{dm}^{3} \mathrm{KCl}$-oldat arányú szuszpenziókkal végeztük. A finommá porított, $2 \mathrm{~mm}$-es szitán átszitált talajok 13-13 db 5 g-os részletéhez $\mathrm{KCl}$-oldatot, majd $0,1 \mathrm{~mol} / \mathrm{dm}^{3} \mathrm{HCl}$-ot, illetve $0,1 \mathrm{~mol} / \mathrm{dm}^{3} \mathrm{NaOH}$-ot adtunk növekvő mennyiségben. A görbék felvételéhez $0 ; 1 ; 2 ; 4 ; 6 ; 8 ; 10 ; 12 ; 14$; 16; 20; 24; 28 meé $\mathrm{H}^{+} / 100 \mathrm{~g}$ talaj, illetve $\mathrm{OH}^{-} / 100 \mathrm{~g}$ talaj sav- és lúgadagokat használtunk. A szuszpenziókat $1 \mathrm{~mol} / \mathrm{dm}^{3} \mathrm{KCl}$ háttér-elektrolit oldattal egészítettük ki $100 \mathrm{~cm}^{3}$-re. Ezt követően 24 órás állás után mértük a pH-t a felrázott szuszpenzióban.

A mért pH-értékeket a hozzáadott sav, illetve lúg mennyiségének függvényében ábrázolva titrálási görbéket kaptunk. A nagy meredekségü és az ellaposodó szakasz határa kijelölésének szubjektivitásából eredő hibát úgy csökkentettük, hogy a mere-

1. táblázat

A talajminták néhány tulajdonsága

\begin{tabular}{|l|c|c|c|c|c|}
\hline \multicolumn{1}{|c|}{$\begin{array}{c}(1) \\
\text { Minta }\end{array}$} & $\begin{array}{c}\mathrm{pH} \\
(\mathrm{KCl})\end{array}$ & $\begin{array}{c}(2) \\
\mathrm{Hu} \%\end{array}$ & $\begin{array}{c}(3) \\
\mathrm{Li} \%\end{array}$ & $\begin{array}{c}(4) \\
\text { T-érték } \\
\text { (meé/100g) }\end{array}$ & $\begin{array}{c}\text { S-érték } \\
\text { (meé/100g) }\end{array}$ \\
\hline Újfehértó & 5,6 & 0,75 & 5 & 0,6 & 2,7 \\
Rakamaz & 3,9 & 0,67 & 6 & 0,4 & 1,5 \\
Nyírgelse & 4,2 & 0,82 & 8 & 1,7 & 2,1 \\
Balkány & 4,7 & 0,75 & 9 & 4,7 & 4,0 \\
Somogysárd & 4,5 & 1,3 & 20 & - & - \\
Gödöllő & 5,0 & 1,00 & 22 & - & - \\
Tanakajd 7 & 5,0 & 1,74 & 23 & 3,7 & 5,2 \\
Nyíregyháza 1 & 4,5 & 1,23 & 25 & 9,8 & 9,1 \\
Nyíregyháza 2 & 4,6 & 1,55 & 27 & 9,1 & 9,9 \\
Kocsord & 4,3 & 1,12 & 34 & 10,4 & 10,3 \\
Tanakajd 8 & 4,5 & 1,78 & 44 & 12,8 & 13,1 \\
Tanakajd 1 & 3,9 & 1,37 & 54 & 4,8 & 4,1 \\
Tanakajd 5 & 3,6 & 1,00 & 57 & 5,2 & 1,7 \\
Tanakajd 2 & 3,8 & 3,54 & 60 & 17,7 & 15,7 \\
Kérsemjén & 4,6 & 1,92 & 63 & 20,4 & 20,8 \\
Gagyvendégi & 4,2 & 3,10 & 68 & 12,3 & 11,7 \\
Putnok & 4,0 & 1,90 & 69 & 19,5 & 18,5 \\
\hline
\end{tabular}

Megjegyzés: -: nem mért érték 
dek szakasz meghatározásához a titrálási görbe deriváltját használtuk FILEP és RÉDLYNÉ (1987-1988), illetve FILEP (1991) módszerének megfelelően. Ezen a meredek és az ellaposodó görbeszakaszok jobban megkülönböztethető módon válnak el egymástól.

\section{Eredmények és értékelésük}

A talajok sav-bázis titrálási görbéinek alakja minden talaj esetében hasonló volt. A kezdeti meredek szakaszt egy további ellaposodó rész követte. A titrálás terhelési tartománya és a titrálási görbe felvételéhez használt mérési pontok száma alapján ezeket tendenciagörbéknek tekinthetjük, melyek a pH változását csak nagy léptékben mutatják be, a kisebb pH-ingadozások nem válnak láthatóvá (FILEP, 1991). Az 1. ábra három, eltérő fizikai féleségü talaj görbéit mutatja be.

A vizsgált talajminták titrálási görbéinek meredek és ellaposodó szakaszára vonatkozó $k$ és $q$ paramétereit a 2. táblázat tartalmazza. A továbbiakban az 1. szakaszra vonatkozó adatokat vizsgáljuk részletesen. A függvény igen pontosan írja le a titrálási görbék kezdeti szakaszát: az R² értéke 0,96-0,99 között változik.

A $k$ paraméter értelmezése FILEP (1991) szerint a következő: egységnyi tömegü bázis/sav által előidézett kezdeti $\mathrm{pH}$-változás $\left(\Delta \mathrm{pH} / 1\right.$ meé $\mathrm{OH}^{-} / 100 \mathrm{~g}$ vagy $\mathrm{H}^{+} / 100$ g). Azaz ez elméletileg nem más, mint reciproka a talaj pufferképességének - ahogyan azt VAN SLYKE (1922) definiálta $\left(\beta=\mathrm{dm}_{\mathrm{b}} / \mathrm{dpH}=-\mathrm{dm}_{\mathrm{s}} / \mathrm{dpH}\right.$; mértékegysége: meé $\mathrm{OH}^{-}$vagy $\mathrm{H}^{+} / 100 \mathrm{~g}$ talaj/pH), $-\mathrm{a}$ kezdeti, $\mathrm{m}_{\mathrm{b}}=0$, ill. $\mathrm{m}_{\mathrm{s}}=0$ pontban. İgy a

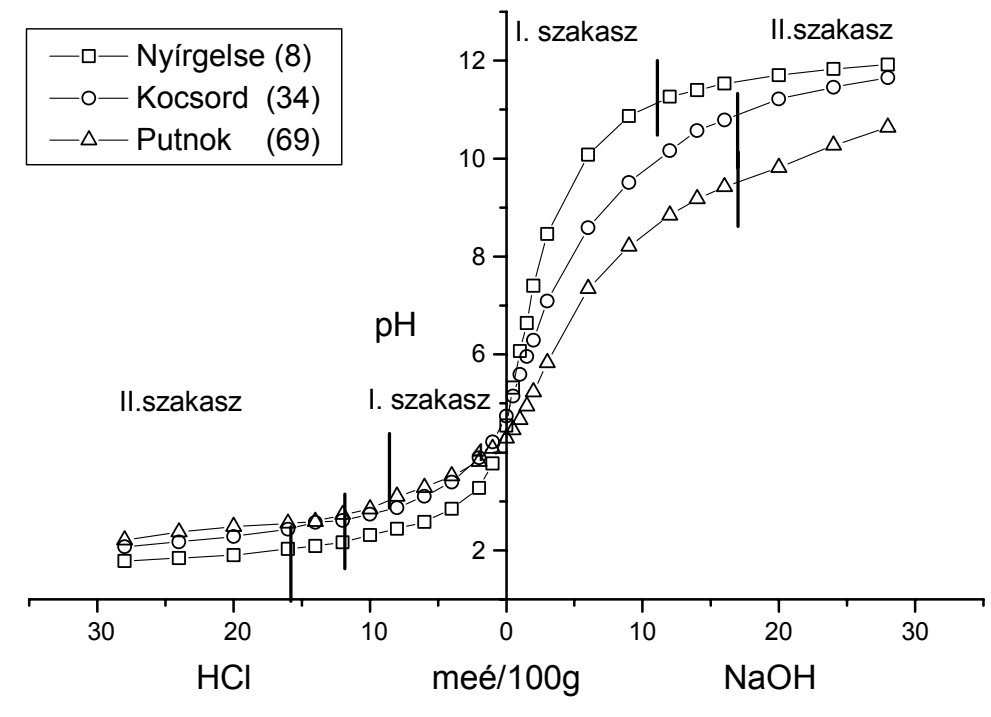

1. ábra

Különböző fizikai féleségü talajok titrálási görbéi. Zárójelben az agyag+iszap\% értékei. A függőleges vonalak a szakaszhatárokat mutatják 


\section{2. táblázat}

A titrálási görbék két szakaszát leíró függvény $q\left(\Delta \% \mathrm{pH} / \Delta \%\right.$ meé $\mathrm{H}^{+}$vagy $\mathrm{OH}^{-} / 100 \mathrm{~g}$ talaj$)$ és $k\left(\Delta \mathrm{pH} / 1\right.$ meé $\mathrm{H}^{+}$vagy $\mathrm{OH}^{-} / 100 \mathrm{~g}$ talaj) paraméterei

\begin{tabular}{|c|c|c|c|c|c|c|c|c|}
\hline \multirow{4}{*}{$\begin{array}{c}(1) \\
\text { Minta }\end{array}$} & \multicolumn{4}{|c|}{ (2) I. Szakasz } & \multicolumn{4}{|c|}{ (4) II. Szakasz } \\
\hline & \multicolumn{8}{|c|}{ (3) Titráló oldat } \\
\hline & \multicolumn{2}{|c|}{$\mathrm{NaOH}$} & \multicolumn{2}{|c|}{$\mathrm{HCl}$} & \multicolumn{2}{|c|}{$\mathrm{NaOH}$} & \multicolumn{2}{|c|}{$\mathrm{HCl}$} \\
\hline & $q$ & $\mathrm{k}$ & $q$ & $\mathrm{k}$ & $q$ & $\mathrm{k}$ & $q$ & $\mathrm{k}$ \\
\hline Újfehértó & 0,61 & 1,35 & 0,37 & 1,37 & 0,68 & 0,10 & 0,69 & 0,08 \\
\hline Rakamaz & 0,61 & 1,65 & 0,46 & 0,69 & 0,63 & 0,14 & 0,69 & 0,09 \\
\hline Nyírgelse & 0,55 & 1,86 & 0,43 & 0,88 & 0,68 & 0,10 & 0,59 & 0,12 \\
\hline Balkány & 0,49 & 1,95 & 0,39 & 1,07 & 0,72 & 0,08 & 0,89 & 0,05 \\
\hline Somogysárd & 0,61 & 1,36 & 0,45 & 0,86 & 0,50 & 0,29 & 0,65 & 0,11 \\
\hline Gödöllő & 0,66 & 1,09 & 0,44 & 1,11 & 0,58 & 0,21 & 0,62 & 0,12 \\
\hline Tanakajd 7 & 0,59 & 1,24 & 0,46 & 0,94 & 0,55 & 0,15 & 0,62 & 0,12 \\
\hline Nyíregyháza 1 & 0,63 & 1,07 & 0,55 & 0,54 & 0,82 & 0,07 & 0,79 & 0,05 \\
\hline Nyíregyháza 2 & 0,73 & 0,80 & 0,58 & 0,58 & 0,70 & 0,14 & 0,74 & 0,07 \\
\hline Kocsord & 0,64 & 1,08 & 0,52 & 0,61 & 0,63 & 0,18 & 0,87 & 0,05 \\
\hline Tanakajd 8 & 0,63 & 1,10 & 0,60 & 0,47 & 0,88 & 0,11 & 0,70 & 0,08 \\
\hline Tanakajd 1 & 0,78 & 0,68 & 0,58 & 0,38 & 1,22 & 0,04 & 0,68 & 0,07 \\
\hline Tanakajd 5 & 0,89 & 0,39 & 0,58 & 0,32 & - & - & 0,69 & 0,06 \\
\hline Tanakajd 2 & 0,75 & 0,69 & 0,66 & 0,25 & 0,76 & 0,13 & 0,83 & 0,05 \\
\hline Kérsemjén & 0,74 & 0,75 & 0,59 & 0,46 & 0,80 & 0,21 & 0,85 & 0,05 \\
\hline Gagyvendégi & 0,66 & 0,81 & 0,51 & 0,57 & 1,09 & 0,08 & 0,78 & 0,06 \\
\hline Putnok & 0,74 & 0,71 & 0,61 & 0,35 & 0,98 & 0,11 & 1,50 & 0,01 \\
\hline
\end{tabular}

Megjegyzés: - nem illeszthető a függvény

$k$ paraméter alkalmas a sav-bázis érzékenység jellemzésére. Értéke minél kisebb, annál nagyobb a talaj eredeti pufferképessége.

FILEP (1991) a $q$ paramétert úgy írja le, mint „a pH-változás sebességét jellemző konstans". A függvényböl következően a $q$ azt mutatja meg, hogy a sav-, vagy bázisterhelés $1 \%$-os növelésével hány $\%$-kal változik a $\mathrm{pH}$ (mértékegysége: $\Delta \% \mathrm{pH}$ $/ \Delta \%$ meé $\mathrm{H}^{+}$vagy $\mathrm{OH}^{-} / 100 \mathrm{~g}$ talaj). A $q$ tehát a pufferképesség változásának tendenciáját jellemző paraméter, melynek fontos határértékei a következőek (2. ábra):

ha $q=1$, akkor a talaj kezdeti pufferképessége nem változik,

ha $q<1$, akkor a pufferképesség nö,

ha $q>1$, akkor a pufferképesség csökken a sav/lúg adagolással.

A vizsgált talajoknál minden esetben $q<1$, azaz a terhelések növekedésével a pufferképesség nő. Részletesebb, kisebb sav-/lúgterhelési tartományt lefedő, több pontból álló titrálási görbék tanulmányozásával valószínúleg olyan szakaszok is láthatóvá válhatnak, ahol a $q>1$.

A függvényparaméterek jobb megértéséhez meg kell vizsgálnunk, hogy a vizsgált talajok titrálási görbéinek első szakaszára elvégzett függvényillesztés alapján a $k$ és $q$ értékek milyen viszonyban, összefüggésben vannak egymással. Ahogyan ez a 3. ábrán látható: a $q$ érték növekedése a $k$ értékének csökkenését vonja maga után. 


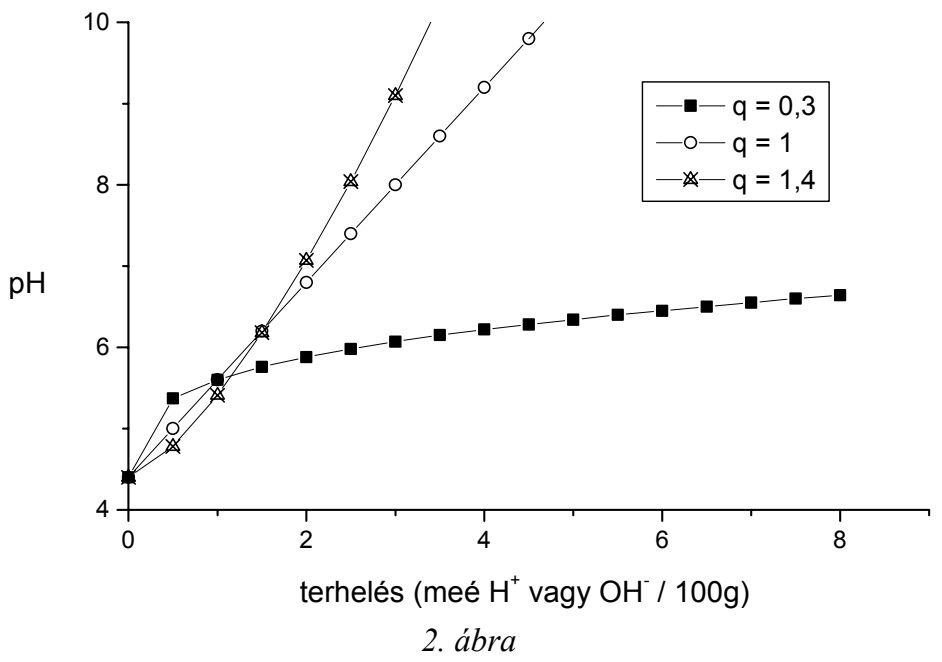

Három hipotetikus titrálási görbe a ráillesztett függvénnyel. A kezdeti pH és a kezdeti pHváltozás mértéke megegyező $\left(\mathrm{pH}_{0}=4,4 ; \mathrm{k}=1,2\right)$

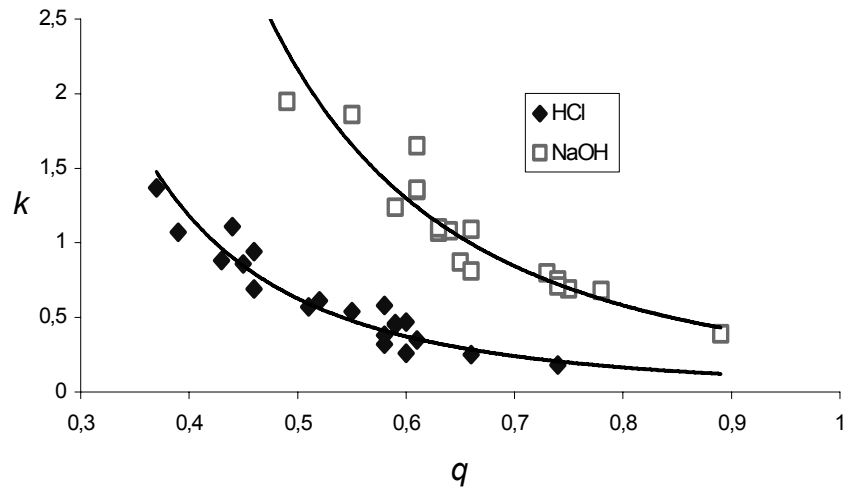

3. ábra

A titrálási görbe I. szakaszára vonatkozó kezdeti pH-változás $(k)$ és a változás tendenciájának $(q)$ kapcsolata a savas és lúgos titrálás esetén

Azaz, ha a talaj kezdeti pufferképessége nagy (a $k$ értéke kicsi), akkor a $q$ értéke az egyhez tart, azaz a pufferképesség változása egyre kisebb lesz. A nagy sav/lúg pufferoló képességü talajok pufferképessége a sav-/lúgadagolás hatására nem változik meg számottevően, míg azok a talajok, amelyek kezdeti puffereló képessége kicsiny már kis mennyiségü sav/lúg hatására veszítenek pufferkapacitásukból. Ez a függvénykapcsolat azt is jelenti, hogy a függvénynek a kezdeti sav-bázis érzékenységet jellemző értékéből $(k)$ következtetni lehet a talaj pufferképességének változási tendenciájára. A $k$ és $q$ paraméterek között hatványösszefüggést feltételezve a következő regressziós egyenleteket kapjuk: 


$\begin{array}{lll}\mathrm{NaOH} \text { titrálás } & k=0,31 \cdot q^{-2,8} & R^{2}=0,91 * * * \\ \mathrm{HCl} \text { titrálás } & k=0,1 \cdot q^{-2,7} & R^{2}=0,89 * * *\end{array}$

A $k-q$ függvénykapcsolat további következménye, hogy létezik egy $k$ határérték, ami felett a pufferképesség változási tendenciája növekvő, alatta csökkenő, az adott értéknél pedig nem változik. Mindez egyszerüen levezethető a regressziós egyenletekből, hiszen lúgos titrálásnál:

ha $k>0,31$, akkor $q<1$, ha $k=0,31$, akkor $q=1$, ha $k<0,31$, akkor $q>1$.

Ugyanez a határérték a vizsgált mintáink esetében savterhelésre: $k=0,1$. A $k<$ 0,31, ill. < 0,1 szituáció csak a görbe matematikai konzekvenciáiból adódik, ilyen mérési eredmény mintáink esetében nem adódott.

A titrálási görbék II. szakaszán tapasztalt $k$ és $q$ értékek esetében is hasonló összefüggés áll fenn.

A kezdeti pH-változás $(k)$ és a változás tendenciája $(q)$ között tapasztalt összefüggés hátterének megismerése érdekében megvizsgáltuk a két függvényparaméter és a talajtulajdonságok kapcsolatát. A regressziós egyenletek alapján azt tapasztaltuk, hogy a növekvő humusztartalommal és leiszapolható rész mennyiséggel a kezdeti pH-változás egyre kisebb, a pufferképesség változásának tendenciája viszont egyre közelebb esik az 1-es értékhez. Azaz, nagy kolloidtartalom esetén a pufferképesség egyre kevésbé változik a titrálás során: nagy sav-, illetve lúgterhelésnél is hasonló meredekségü a titrálási görbe. A kezdeti pH-változásnak $(k)$ és a változás tendenciájának $(q)$ kapcsolata a humusztartalommal hatványfüggvény szerint, a leiszapolható rész mennyiségével lineárisan változik:

$$
\begin{array}{ll}
q(\text { sav })=0,003 \cdot L i \%+0,41 & R^{2}=0,66^{* * *} \\
k(\text { sav })=-0,01 \cdot L i \%+1,06 & R^{2}=0,64 * * * \\
q(\text { lúg })=0,003 \cdot L i \%+0,56 & R^{2}=0,54 * * * \\
k(\text { lúg })=-0,016 \cdot L i \%+1,65 & R^{2}=0,71^{* * *} \\
q(\text { sav })=0,47 \cdot H u \%{ }^{0,26} & \\
k(\text { sav })=0,78 \cdot H u \%^{-0,68} & R^{2}=0,55 * * * \\
q(\text { lug })=0,62 \cdot H u \%^{0,16} & R^{2}=0,51^{* *} \\
k(\text { lúg })=1,28 \cdot H u \%^{-0,56} & R^{2}=0,38^{*}
\end{array}
$$

Látható, hogy a kezdeti pH-változás nagysága $(k)$ fordított arányban áll a talaj kolloidtartalmával. Ez érthető is, hiszen a nagyobb felületen lejátszódó kationcserereakciók a talajhoz adott sav, illetve lúg pH-módosító hatását jobban képesek tompítani, így a $\mathrm{pH}$ változása kisebb. A $q$ értékének a kolloidtartalommal való kapcsolatára a $k$ segítségével adhatunk magyarázatot. Ehhez az 1. ábrán bemutatott Nyírgelse és Kocsord minták $\mathrm{NaOH}$-dal való titrálásának példáját használjuk fel. A homoktalaj (Nyírgelse) kezdeti pH-változása 1,86, a vályogé (Kocsord) 1,08. A kis kolloidtartalmú talaj tehát már kisebb lúgterhelés hatására is nagyobb $\mathrm{pH}$ változással reagál és viszonylag kis terhelésnél eléri az ellaposodó szakasz kezdetét jelentő $\mathrm{pH}=\sim 11$ értéket; a változás tendenciáját mutató konstans $(q)$ értéke 0,55 . A 
vályogtalaj viszont nagyobb terhelések hatására is kisebb pH-változást mutat, mint a homoktalaj, ezért a $q$ értéke magasabb $(0,64)$.

Általánosan fogalmazva a kis pufferképességű talajoknál a kezdeti nagymértékü pH-változás után a pufferképesség hamar kimerül, így a titrálási görbe, már viszonylag kis terhelés után ellaposodik és így éri el a megnövekedett pufferképesség (II. szakasz) határát. A nagy pufferképességü talajok viszont a titrálás teljes I. szakaszában, még a nagyobb terheléseknél is közel állandó pufferképességet mutatnak, így a titrálási görbe meredeksége kevésbé változik a nagy sav-, illetve lúgadagok alkalmazása esetén.

A II. szakaszra vonatkozó kezdeti pH-változással és a változás tendenciájával a talajtulajdonságok nem mutattak kapcsolatot.

\section{Összefoglalás}

Munkánkban a FILEP (1991) által javasolt, titrálási görbék leírására alkalmas függvény paramétereinek vizsgálatát végeztük el 17 talajból álló mintakollekcióra alapozva. A függvény a következö:

$$
p H_{x}=p H_{0}+k\left(m_{b}\right)^{q} \text { és } p H_{x}=p H_{0}-k\left(m_{s}\right)^{q}
$$

ahol: $p H_{x}$ a talajszuszpenzió egyensúlyi $\mathrm{pH}-\mathrm{ja}$ meghatározott mennyiségü lúg $\left(\mathrm{m}_{\mathrm{b}}\right)$, vagy sav $\left(\mathrm{m}_{\mathrm{s}}\right)$ hozzáadása után, $p H_{0}$ a szuszpenzió kezdeti $\mathrm{pH}$-ja (a titrálás zéruspontja), $k$ az egységnyi tömegủ bázis, vagy sav által elöidézett kezdeti $\mathrm{pH}$-változást mutatja, $q$ pedig a $\mathrm{pH}$ változás sebességét jellemzö konstans.

A talajok titrálási tendenciagörbéinek első, meredek szakaszára végeztük el a függvény illesztését. Főbb megállapításaink a következők:

A FILEP (1991) által javasolt függvény $k$ (egységnyi tömegü bázis/sav által elöidézett kezdeti $\mathrm{pH}$-változás $\left(\Delta \mathrm{pH} / 1\right.$ meé $\mathrm{OH}^{-} / 100 \mathrm{~g}$ vagy $\left.\left.\mathrm{H}^{+} / 100 \mathrm{~g}\right)\right)$ és $q(1 \%$-os sav-, vagy bázisterhelés növelés hatására bekövetkezett \%-os pH-változás $(\Delta \% \mathrm{pH} /$ $\Delta \%$ meé $\mathrm{H}^{+}$vagy $\mathrm{OH}^{-} / 100 \mathrm{~g}$ talaj)) paramétere negatív korreláció szerint, feltehetöen hatványosan összefügg:

$$
\begin{array}{lll}
\mathrm{NaOH} \text { titrálás } & k=0,31 \cdot q^{-2,8} & R^{2}=0,91 * * * \\
\mathrm{HCl} \text { titrálás } & k=0,1 \cdot q^{-2,7} & R^{2}=0,89 * * *
\end{array}
$$

Ezen összefüggés miatt feltehetően már az egyik paraméter is elégséges a talaj pufferképességének leírásához.

A kezdeti $\mathrm{pH}$-változás nagysága $(k)$ fordított, míg a változás tendenciáját jellemző konstans $(q)$ egyenes arányban áll a talaj kolloidtartalmával.

Kulcsszavak: talajok sav-bázis pufferkapacitása, titrálási görbék, függvényillesztés, pH-változás 


\section{Irodalom}

Federer, C. A. \& Hornbeck, J., 1985. The buffer capacity of forest soils in New England. Water, Air and Soil Poll. 26. 163-173.

FILEP GY., 1991. A talajok sav-bázis titrálási görbéinek és pufferkapacitásának új értékelési módszere. Agrokémia és Talajtan. 40. 195-201.

FILEP GY. \& RÉDLY L.-NÉ, 1988. A talajsavanyúság formáinak és a talaj sav-bázis pufferoló hatásának értelmezése. Agrokémia és Talajtan. 36-37. 79-96.

GiLlman, G. P., 1979. A proposed method for the measurement of exchange properties of highly weathered soils. Aust. J. Soil. Res. 17. 129-139.

HARGITAI L., 1988. A talaj szervesanyag-tartalmának meghatározása Tyurin módszerével. In: Talaj- és agrokémiai vizsgálati módszerkönyv 2. (Szerk.: BUZÁs I.) 152 154. Mezőgazdasági Kiadó. Budapest.

MurÁNYI, A., 1987. Soil acidification and the soil properties. Zeszyty Problemowe Postepow Nauk Rolniczych. 344. 123-126.

VAN SLYKE D. D., 1922. On the measurement of buffer values and on the relationship of buffer value to the dissociation constant of the buffer and the concentration and reaction of buffer solution. J. Biol Chem. 52. 525-570.

VÁRALlyAY GY., 1993. A talaj leiszapolható részének meghatározása (rövidített mechanikai elemzés). In: Talaj- és agrokémiai vizsgálati módszerkönyv 1. (Szerk. BUZÁs I.) 42-43. INDA 4231 Kiadó. Budapest.

YUAN, G. \& LAVKULICH, M., 1995. Acid buffering capacity factor of forest soils. Commun. Soil Sci. Plant Anal. 26. 51-60.

Érkezett: 2006. november 28. 


\title{
Method for evaluating the acid-base buffering capacity of soils
}

\author{
M. RÉKÁSI and T. FILEP \\ Research Institute for Soil Science and Agricultural Chemistry of the \\ Hungarian Academy of Sciences, Budapest
}

\section{Summary}

In the present work the parameters of equation (1), suggested by FILEP (1991) were studied on 17 Hungarian soil samples with different physical and chemical characteristics. The equation is suitable for describing soil acid-base titration curves.

$$
p H_{x}=p H_{0}+k\left(m_{b}\right)^{q} \text { and } p H_{x}=p H_{0}-k\left(m_{s}\right)^{q}
$$

where: $p H_{x}$ is the equilibrium $\mathrm{pH}$ of the soil suspension, $m_{b}$ and $m_{s}$ are the amount of added base and acid, $\mathrm{pH}_{0}$ is the suspension $\mathrm{pH}$ at the beginning of the titration, $k$ is the initial $\mathrm{pH}$ change caused by 1 unit mass of acid or base, and $q$ is a constant representing the rate of $\mathrm{pH}$ change.

The suspensions ( $1: 20$ soil: $1 M \mathrm{KCl}$ solution) were titrated with $0.1 M \mathrm{HCl}$ and $0.1 M$ $\mathrm{NaOH}$ as follows: $0 ; 1 ; 2 ; 4 ; 6 ; 8 ; 10 ; 12 ; 14 ; 16 ; 20 ; 24 ; 28$ meq H$^{+} / 100$ g soil, or $\mathrm{OH}^{-}$ $/ 100 \mathrm{~g}$ soil. The suspension $\mathrm{pH}$ was measured after 24 hours of equilibration. To obtain the titration curves, the $\mathrm{pH}$ values were plotted against the amount of added acid or base. The function is not able to describe the whole titration curve, so the curves were divided into two sections (Figure 1), and the function was fitted to the first and second parts of the curve separately. Hereinafter the parameters of the first steep section are discussed.

The main findings can be summarized as follows:

The initial $\mathrm{pH}$ change caused by 1 unit mass of acid or base $\left(\Delta \mathrm{pH} / 1 \mathrm{meq} \mathrm{H}^{+} / 100 \mathrm{~g}\right.$ or $\mathrm{OH}^{-} / 100 \mathrm{~g}$ soil $)$ and the constant representing the rate of $\mathrm{pH}$ change $\left(\Delta \% \mathrm{pH} / \Delta \%\right.$ meq $\mathrm{H}^{+}$ or $\mathrm{OH}^{-} / 100 \mathrm{~g}$ soil) are in negative correlation. The relation between them can be described by a power function.

$$
\begin{array}{lll}
\mathrm{NaOH} \text { titration } & \mathrm{k}=0.31 \cdot \mathrm{q}^{-2.8} & \mathrm{R}^{2}=0.91 * * * \\
\mathrm{HCl} \text { titration } & \mathrm{k}=0.1 \cdot \mathrm{q}^{-2.7} & \mathrm{R}^{2}=0.89 * * *
\end{array}
$$

This means that the initial $\mathrm{pH}$ change $(\mathrm{k})$ determines the tendency of $\mathrm{pH}$ change $(\mathrm{q})$. For example, in the case of $\mathrm{HCl}$ titration if $\mathrm{k}<0.1$ then $\mathrm{q}>1$ ( $\mathrm{pH}$ change will increase), if $\mathrm{k}>0.1$ then $\mathrm{q}<1$ ( $\mathrm{pH}$ change will decrease) and if $\mathrm{k}=0.1$ then $\mathrm{q}=1$ ( $\mathrm{pH}$ change will stay at the initial level). Because of this correlation a single parameter might be sufficient to describe the acid-base buffering capacity of the soil.

The soil colloid content is negatively correlated with the initial $\mathrm{pH}$ change $(\mathrm{k})$ and positively with the rate of $\mathrm{pH}$ change (q) (See equations 4-10).

Table 1. Selected parameters of the soil samples. (1) Sample. (2) Organic matter \%. (3) Clay+silt \%. (4) Cation exchange capacity, CEC, meq/100 g. (5) Exchangeable bases, meq/100 g. Note: not measured value.

Table 2. Function parameters $q\left(\Delta \% \mathrm{pH} / \Delta \%\right.$ meq $\mathrm{H}^{+}$or $\mathrm{OH}^{-} / 100 \mathrm{~g}$ soil $)$ and $k(\Delta \mathrm{pH} / 1$ meq $\mathrm{OH}^{-} / 100 \mathrm{~g}$ or $\left.\mathrm{H}^{+} / 100 \mathrm{~g}\right)$ describing the two sections of the titration curve. 
(1) Sample. (2) Section I. (3) Section II. (4) Titration solution. Note: Function cannot be fitted

Fig. 1. Titration curves for soils with different texture. The clay + silt $\%$ values are given in brackets. Vertical lines indicate the two sections of the titration curves.

Fig. 2. Three hypothetical titration curves and the fitted function. $\mathrm{pH}_{0}$ and $\mathrm{k}$ are identical in all cases $\left(\mathrm{pH}_{0}=4.4 ; \mathrm{k}=1.2\right)$.

Fig. 3. Relationship between the initial $\mathrm{pH}$ change $(k)$ and the tendency of the $\mathrm{pH}$ change $(q)$ of the first section of the titration curve in the case of acid and base $(\mathrm{HCl}$ and $\mathrm{NaOH})$ titrations. 